\title{
Sentimental Herding: The Role of Regional and Global Shocks in Egyptian and Saudi Stock Markets'
}

Ali G̈̈UERCIN, Department of Management, Faculty of Economics, Administrative and Social Sciences, Istanbul Gelisim University, Turkey; e-mail: aguvercin@gelisim.edu.tr

\section{Duygusal Sürü Davranışı: Mısır ve Suudi Arabistan Borsalarındaki Bölgesel ve Küresel Şokların Rolü ${ }^{2}$}

\begin{abstract}
In this study, the existence of market-wide herding for Egypt and Saudi stock markets is investigated using state-space methodology developed by Hwang and Salmon (2004). The objective is not just to provide evidence for herding, but also evaluate the effect of regional and global shocks on herding behavior for these markets. Results show that herding exists only in Egypt. Moreover, for herd parameter in Egypt, mortgage crisis and Egyptian military takeover are the only significant factors. As expected, these factors cause fading effect on herd parameter, strengthening adverse herding. Contrary to expected, oil return or oil return volatility has no impact on herd parameter.

Keywords

Sentimental Herding, State-Space Model, Cross-Sectional Volatility, Emerging Market.

JEL Classification Codes : $\quad$ C12, C13, C30, G14.

\section{$\ddot{\mathbf{O} z}$}

Bu çalışmada, Mısır ve Suudi hisse senedi piyasaları için, piyasa genelinde duygusal sürü davranışının varlığ incelenmiştir. Bölgesel ve küresel şokların etkisi de incelenmiştir. Sonuçlar gütmenin, duygusal sürü davranışının sadece Mısır'da var olduğunu göstermektedir. Ayrıca, Mısır'da duygusal sürü parametresi için, mortgage krizi ve Mısır askeri devrimi önemli faktörlerdir. Beklendiği gibi, bu faktörlerin olumsuz gütme güçlendirilmesi, duygusal sürü parametresinin üzerindeki etkisini azaltma nedenidir. Duygusal sürü parametresine petrol getirisi veya petrol getiri volatilitesinin bir etkisinin olmadığ görünmektedir.
\end{abstract}

I I would like to thank Nazmi Demir and M. Nihat Solakoğlu for their helpful comments and help with the statespace estimation.

2 Nazmi Demir ve M. Nihat Solakoğlu'na faydalı yorumlarl ve yardımları için ve durum-uzay tahminleri için teşekkür ederim. 
Anahtar Sözcükler
: Sürü Davranışı, Durum-Uzay Modeli, Yatay Kesit Oynaklık, Yükselen Piyasalar.

\section{Introduction}

This study investigates the existence of sentimental herding, or herding towards the market portfolio using the state-space methodology developed by Hwang and Salmon (2004). Moreover, the analysis looks at the effect of regional and global shocks on the herd behavior. Understanding the herd behavior in a market is important as the existence of herding may indicate movement away from market efficiency.

Herding exists when a group of investors follow another group of investors (or investor) in forming their investment strategies and hence this group decides by totally ignoring market and firm level fundamentals (Bikhchandani \& Sharma, 2001; Borensztein \& Gelos, 2001). Herding studies generally focus on two approaches. In one approach, they try to explain the behavior of investors to follow the actions of others (Oehler \& Chao, 2000; Gompers \& Metrick, 2001; Kim et al., 2005; Puckett et al., 2007). In the other approach, a "market-wide" approach is used to isolate the herd behavior. The most commonly used methods focus on the cross-sectional dispersion of returns (CSSD) (Christie \& Huang, 1995) or cross-sectional absolute deviation of returns (CSAD) (Chang et al., 2000). Both these methods use total risk. Another method is to use the systematic risk only to calculate the cross-sectional dispersion and to assume that herding occurs because of sentiment rather than market or firm level fundamentals (Hwang \& Salmon, 2004).

This study uses the last method by Hwang and Salmon (2004) to analyze the existence of market-wide herding in the Saudi and Egypt stock markets and the possible effects of regional and global factors on the herd behavior. Markets in the regions are relatively newer, not fully open and smaller in size compared to developed countries. As Solakoglu and Demir (2014) shows it is more likely to observe sentimental herding when markets are smaller and investors are less informed. Hence, we can assume that investors of these two markets are not completely informed about the market fundamentals and it is more likely to observe sentimental herding in this market.

There are a number of studies looking at the herding behavior for Middle East markets and factors contributing to herding. For example, Demirer and Ulussever (2011), based on return-dispersion, show that the driving force for herding behavior is oil in some of the Middle East markets. In another study, Balcilar et al. (2013) indicate that global financial risks are important for herding. Dalia et al. (2014) find no evidence of herding in the Egyptian stock market. This study uses a sample of the 20 most-traded stocks and return- 
dispersion forthe analysis. For all Gulf Cooperation Council countries, Shawkat (2012) investigates herding behavior and finds evidence of herding except for Qatar ${ }^{3}$.

The study is organized as follows. In section 2, the data and estimation methodology is described. Section 3 presents findings, and finally in Section 4, conclusions are provided.

\section{Data and Methodology}

All the data used for the analysis are obtained from Thomson's Data Stream database. The daily data for Saudi stock market starts with the beginning of March 2001 and ends at June of 2014, giving us 154 monthly beta estimates for Tadawul stock exchange. For Egypt, daily data is obtained between July 2002 and May 2014, giving us 140 monthly observations. Using daily price and index data, daily log-returns are calculated. To calculate monthly beta estimates, daily log returns are regressed on daily market index return using Ordinary Least Squares (OLS).

The method used follows Hwang and Salmon (2004) and briefly explained below. The model is based on a relationship between observed biased beta $\left(\beta_{i m t}^{b}\right)$ and unobserved true beta $\left(\beta_{\text {imt }}\right)$ as follows (see also Demir et al., 2014; Solakoglu \& Demir, 2014):

$$
\frac{E_{t}^{b}\left(r_{i t}\right)}{E_{t}\left(r_{m t}\right)}=\beta_{i m t}^{b}=\beta_{i m t}-h_{m t}\left(\beta_{i m t}-1\right)
$$

where $E_{t}^{b}\left(r_{i t}\right)$ is the biased short-run conditional expectation on the excess return of asset $\mathrm{i}$ at time $\mathrm{t}$ and $E_{t}\left(r_{m t}\right)$ is the conditional expectation of the market excess return at time $\mathrm{t}$. The unobserved herd behavior indicator $h_{m t}$ is the parameter assumed to be proportional to the deviation of the individual true beta from market beta, or unity. The cross-sectional variation of $\beta_{i m t}^{b}$ is:

$$
\operatorname{Std}_{c}\left(\beta_{i m t}^{b}\right)=\operatorname{Std}_{c}\left(\beta_{i m t}\right)\left(1-h_{m t}\right)
$$

And in logarithms of [2], we get,

$$
\ln \left[\operatorname{Std}_{c}\left(\beta_{i m t}^{b}\right)\right]=\ln \left[\operatorname{Std}_{c}\left(\beta_{i m t}\right)\right]+\ln \left(1-h_{m t}\right)
$$

We may now re-write equation [3] as: 


$$
\ln \left[S t d_{c}\left(\beta_{i m t}^{b}\right)\right]=\mu_{m}+H_{m t}
$$

where $\mu_{\mathrm{m}}=\ln \left[\operatorname{Std}_{c}\left(\beta_{\text {imt }}\right)\right]$ is assumed constant in the short run and $H_{m t}=\ln \left(1-h_{m t}\right)$. Hwang and Salmon (2004) now allow herding, $H_{m t}$, to follow a dynamic process $\operatorname{AR}(1)$, and the system becomes:

$$
\begin{aligned}
& \ln \left[\operatorname{Std}_{c}\left(\beta_{i m t}^{b}\right)\right]=\mu_{t}+H_{m t}+v_{m t} \\
& H_{m t}=\varphi_{m} H_{m t-1}+\eta_{m t}
\end{aligned}
$$

where the two error terms, $v_{m t} \sim \operatorname{iid}\left(0, \sigma_{m v}^{2}\right)$ and $\eta_{m t} \sim \operatorname{iid}\left(0, \sigma_{m \eta}^{2}\right)$, respectively. To calculate cross-sectional standard deviation of betas for each month, the following equation is used:

$$
\operatorname{Std}(\beta)_{t}=\sqrt{\frac{\sum_{i=1}^{n}\left(\text { beta }_{i t}-\overline{\text { beta }}_{t}\right)^{2}}{n-1}}
$$

Model 1 (equation 5) can be modified to include two market fundamentals for robustness: market volatility and market returns. If $\mathrm{H}_{\mathrm{mt}}$ becomes insignificant after the inclusion of market volatility and returns, then changes in $\operatorname{Std}_{c}\left(\beta_{i m t}^{b}\right)$ can be explained by market fundamentals rather than by herding and hence there will be no evidence of herding.

$$
\begin{aligned}
& \ln \left[\operatorname{Std}_{c}\left(\beta_{i m t}^{b}\right)\right]=\mu_{m}+H_{m t}+\theta_{c 1} \ln \sigma_{m t}+\theta_{c 2} r_{m t}+v_{m t} \\
& H_{m t}=\varphi_{m} H_{m t-1}+\eta_{m t}
\end{aligned}
$$

whereln $\sigma_{m t}$ and $r_{m t}$ represent $\log$ market volatility and return in time period t. While equations [5] shows the base model (model 1), equations in [6] indicate the robust model (Model 2).

In model 1 and $2, \mathrm{H}_{\mathrm{mt}}$ is the latent state variable and the herding parameter is obtained by $\mathrm{h}_{\mathrm{mt}}=1-\exp \left(\mathrm{H}_{\mathrm{mt}}\right)$. To investigate the role of regional and global factors on herding behavior, equation [7] is used.

$$
h_{m t}=\alpha_{0}+\alpha_{1} D_{\text {crisis }}+\alpha_{2} D_{\text {syr }}+\alpha_{3} D_{\text {egypt }}+\alpha_{4} r_{\text {oil }}+\alpha_{5} \ln \left(S D_{\text {oil }}\right)+v_{\text {ht }}
$$

Where we assume $v_{\mathrm{ht}}$ iid $\left(0, \sigma^{2}\right.$ vht $)$. In this equation, we use $\mathrm{D}_{\text {crisis }}=1$ for months of 2007-2008 otherwise "0" to represent the mortgage crisis, $D_{\text {syr }}=1$ from the beginning March 2011 through the end of the sample period otherwise "0" for the Syrian Civil War, $\mathrm{D}_{\text {egypt }}=1$ from July 2013 to July 2014 when the presidential election ended, otherwise "0" for the Egyptian Coup military take over. We also use oil return and return volatility as a regional risk indicator in the equation. $r_{\text {oil }}$ is $\log$ returns of World Brent oil prices and $\ln \left(\mathrm{SD}_{\text {oil }}\right)$ is the $\log$ of standard deviation of oil return. 


\section{Findings}

The Kalman filter estimates of the state-space model (Model 2) are reported in Table 1. First of all, for Saudi market there is no evidence of herd behavior. However, for Egypt, even after market return and market return volatility included into the state equation, parameters of Model 2 - parameters $\varphi_{\mathrm{m}}$ (the persistence indicator) of $\operatorname{AR}(1)$ and $\sigma^{2}{ }_{m \eta}$ (the variance of the state equation) - stays highly significant, indicating investors in Egypt stock market exhibit herd behavior.

Table: 1

Estimation Results for Model 2

\begin{tabular}{|l|c|c|}
\hline Parameters & Egypt & S.Arabia \\
\hline$\mu_{\mathrm{m}}$ & $-1.984^{* *}$ & $-2.997 \mathrm{n}$ \\
\hline$\varphi_{\mathrm{m}}$ & $0.919^{* *}$ & $0.345 \mathrm{n}$ \\
\hline$\sigma_{\mathrm{m} \eta}$ & $0.005^{* *}$ & $0.096^{* *}$ \\
\hline$\sigma_{\mathrm{mv}}$ & $0.074^{* *}$ & $0.0023 \mathrm{n}$ \\
\hline Market Ret. & $-0.144 \mathrm{n}$ & $-3.795 \mathrm{n}$ \\
\hline Market Vol. & $0.717^{* *}$ & $-0.540^{* *}$ \\
\hline$\sigma_{\mathrm{m} / \mathrm{SDLn} \beta} \%$ & 20.10 & -40.19 \\
\hline Log-lik. & -31.21 & 0.599 \\
\hline Akaike & 0.532 & \\
\hline Highly significant $* * ;$ Significant *; Insignificant $\mathrm{n}$. & \multicolumn{2}{|l}{} \\
\hline
\end{tabular}

The autoregressive coefficient of the $\mathrm{AR}(1)$ process is the persistence parameter in the model and for Egypt this parameter is 0.919 and highly significant. This indicates that of the variance in $\mathrm{H}_{\mathrm{mt}}, 84 \%$ is explained by a one-month-lag of $\mathrm{H}_{\mathrm{mt}}$. As a result, herding dies out slowly in Egypt. Market risk is highly significant with positive sign and hence the betadispersion appears to be driven also by the market risk. Moreover, the signal ratio is $20.1 \%$ for Egypt indicating that sentimental herding has been mild over the period studied.

Figure 1 shows the line charts of sentimental herding for Egypt market only as there was no herding revealed in the Saudi stock market. Inspection of this chart pattern shows that sentimental herding was mild in Egypt as $h_{t}$ swings between -3 and +3 (min and $\max$ are -1 and +1 ). Also, around 2006-2007 and pre-2003, there seems to be adverse herding, where investors, faced with uncertain future, turned to fundamental values about the firm in forming portfolios (see, Hwang \& Salmon, 2004 for details). 
Figure: 1

\section{Herding Pattern}

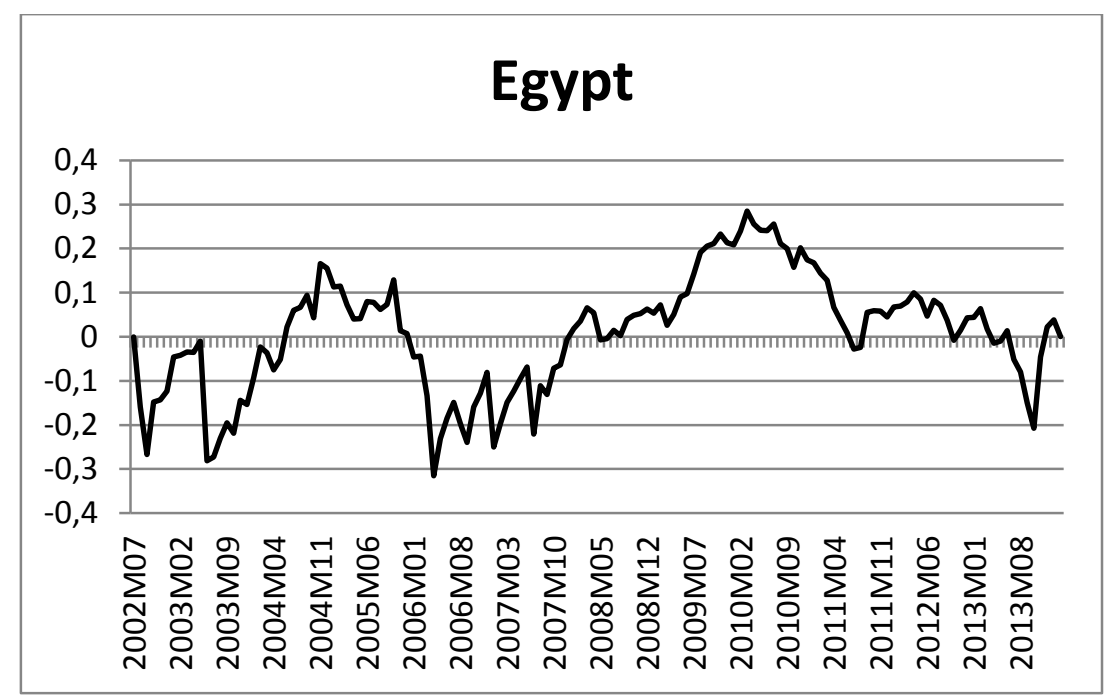

As discussed earlier, the role of regional and global factors on herd behavior is investigated using Equation [7]. Since, there was no evidence of herding, the analysis is conducted only for Egypt. The results are presented in Table 2.

Table: 2

\section{Regional and Global Factors and Herding Score}

\begin{tabular}{|l|l|l|l|l|l|l|l|}
\hline Variables & $\begin{array}{l}\text { Mortgage } \\
\text { Crisis }\end{array}$ & $\begin{array}{l}\text { Syrian Civil } \\
\text { War }\end{array}$ & $\begin{array}{l}\text { Egypt's Coup } \\
\text { D'état }\end{array}$ & Oil returns & $\begin{array}{l}\text { Oil Return } \\
\text { Volatility }\end{array}$ & $\begin{array}{l}\text { Adj R- } \\
\text { Square }\end{array}$ & $\begin{array}{l}\# \\
\text { obs }\end{array}$ \\
\hline & $\begin{array}{l}-0.062 \\
(0.030) * *\end{array}$ & $\begin{array}{l}0.041 \\
(0.033)\end{array}$ & $-0.088(0.053)^{*}$ & $\begin{array}{l}0.010 \\
(0.027)\end{array}$ & $0.023 \quad(0.016)$ & 0.035 & 140 \\
\hline
\end{tabular}

As for the regression results, the impact of the Mortgage crisis on herding is evident in Egypt, which is also verified statistically that the coefficient of the Mortgage crisis is significant. Moreover, the sign of the coefficient, which is negative, indicates that mortgage/global crisis either softened the herding or increased adverse herding in Egypt. This occurrence of adverse herding was also observed in the Turkish market-BIST during the Mortgage crisis (Demir et al, 2014; Solakoğlu, 2014). Adverse herding seems to occur when investors/traders are small and medium in size and had little or no access to market information and confused with uncertainty about the future and current state of the markets.

Interestingly, there does not seem to be an effect of oil return or oil return volatility on investors in the Egypt stock market. From the regression estimates, it also 
appears that the impact of the Syrian conflict, contrary to expectations, is not significant for investors herd behavior. On the other hand, as expected, the Egyptian political intervention in July $2013^{4}$ seems to have a significant impact on herding, with negative sign.

\section{Concluding Remarks}

This study investigates the existence of market-wide herding for Egypt and Saudi stock markets using the state-space methodology developed by Hwang and Salmon (2004). In addition, the role of regional and global factors on herd parameter, if exists, is investigated using ordinary least squares. For regional and global factors, this study focuses on mortgage crisis, Egyptian military takeover, Syrian civil war, oil return and finally oil return volatility to represent the regional risk level.

Results indicate that there is no sentimental herding in Saudi market while investors in Egypt exhibits herd and adverse herd behavior. Furthermore, the herd behavior in Egypt seems to be mild with a slow decay. In terms of regional and global factors, estimation results show that only mortgage crisis and Egyptian military takeover are significant factors in affecting herd behavior. In addition, both these factors cause herding parameter to weaken, implying increased adverse herding when investors faced with significant shocks to the market.

\section{References}

Balcilar, M. \& R. Demirer \& S. Hammoudeh \& A. Khalifa (2013), "Do Global Shocks Drive Investors Herds in Oil-rich Frontier Markets?", Working Paper, 819, 1-28.

Balcilar, M. \& R. Demirer \& S. Hammoudeh (2013), "Investor herds and regime-switching: Evidence from Gulf Arab stock markets", Journal of International Financial Markets Institutions and Money, 23, 295-321.

Bikhchandani, S. \& S. Sharma (2001), "Herd behavior in financial markets: A Review", International Monetary Fund Staff Papers 47, No. 3, 279-310.

Borensztein, E. \& G. Gelos (2001), “A Panic-Prone Pack? The Behavior of Emerging Market Mutual Funds", IMF Working Paper, WP No. 00/198, 1-35.

Chang, E.C. \& J.W. Cheng \& A. Khorana (2000), "An examination of herd behavior in equity markets: An international perspective", Journal of Banking and Finance, 24(10), 16511679; Doi: http://dx.doi.org/10.1016/S0378-4266(99)00096-5.

Christie, W.G. \& R.D. Huang (1995), "Following the pied piper: Do individual returns herd around the market?", Financial Analyst Journal, (July-August), 31-37; Doi: 10.2469/faj.v51.n4.1918. 
Dalia, El-Shiaty \& A.A. Badawi (2014), "Herding Behavior in the Stock Market: An Empirical Analysis of the Egyptian Exchange", Working Paper, No, 37, 1-17.

Demir, N. \& S.F. Mahmud \& M.N. Solakoglu, (2014), "Sentiment and Beta Herding in the Borsa İstanbul (BIST)", in: Risk Management Post-financial Crisis: A Period of Monetary Easing, Vol. 96, Ed: Jonathan A. Batten and Niklas F. Wagner, Emerald Group Publishing Limited, ISBN: 978-1-78441-027-8, 389-400.

Demirer, R. \& T. Ulussever (2011), "Investors herds and oil prices: Evidence from GCC stock markets", Working Paper, Department of Economics and Finance, Southern Illinois University, Edwardsville, 1-22.

Gompers, P. \& A. Metrick (2001), "Institutional Investors and Equity Prices”, Quarterly Journal of Economics, 116, 229-260.

Hwang, S. \& M. Salmon (2004), "Market stress and herding”, Journal of Empirical Finance, 11(4), 585-616.

Kim, K. \& J. Sias (2005), "Institutional herding, business groups and economic regimes: evidence from japan”, Journal of Business, 78(1), 213-242.

Oehler, A. \& G.G. Chao (2000), "Institutional herding in bond markets", Bamberg University Department of Finance, Working Paper, Doi: http://dx.doi.org/10.2139/ssrn.294460, 131.

Puckett, A. \& X. Yan (2007), "The determinants and impact of short-term institutional herding", Working Paper, <http://rssrn.com/abstract=972254>, 1-27.

Solakoglu, N. \& N. Demir (2014), "Sentimental Herding in Borsa İstanbul: Informed versus Uninformed”, Applied Economic Letters, Doi: 10.1080/13504851.2014.902015, 965-968. 